\title{
Okenone as a proxy of water level and redox-conditions in saline stratified Lake Shira (Siberia, Khakassia)
}

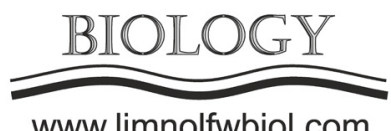

www.limnolfwbiol.com

\author{
Rogozin D.Y. ${ }^{1,2 *}$, Zykov V.V. ${ }^{1}$, Bulkhin A.O.. ${ }^{1,2}$, Darin A.V. ${ }^{3}$, Kalugin I.A. ${ }^{3}$ \\ ${ }^{1}$ Institute of Biophysics SB RAS, Krasnoyarsk, Russia \\ ${ }^{2}$ Siberian Federal University, Krasnoyarsk, Russia \\ ${ }^{3}$ Sobolev Institute of Geology and Mineralogy SB RAS, Novosibirsk, Russia
}

\begin{abstract}
In meromictic saline Lake Shira (southern Siberia, Russia) we revealed the dependence of okenone (specific carotenoid of purple sulfur bacteria) on water level dynamics. Therefore, we have shown that okenone in bottom sediments can be used as a proxy of climate humidity in semi-arid region of Southern Siberia.
\end{abstract}

Keywords: okenone, purple sulfur bacteria, water level, stratification, paleoclimate

\section{Introduction}

Lake Shira (N 54.30, E 90.11) is located in semi-arid steppe landscapes of Southern Siberia in the steppe zone of the northern part of the Minusinsk valley (Republic of Khakassia, Russia). The lake is meromictic most of years, however the holomictic state was registered in 2015-2016. The lake level is sensitive to moisture fluctuations. Carotenoids of sulfur bacteria are stable in bottom sediments and commonly are used as a proxy of meromictic conditions. We compare the documented water level dynamics with data of multi-year observations of sediment fluxes of okenone with stratification stability and okenone content in uppermost annual sediment layers.

\section{Materials and methods}

Sediments were sampled annually in March 2013-2018 by freeze-corer in order to obtain the nondisturbed uppermost annual varves. The sediment traps were exposed seasonally in 2012-2018 at the center of the lake near bottom. The okenone was measured in sediment cores and traps by a high-performance liquid chromatography (HPLC). Purple sulfur bacteria abundance was estimated by microscopy. The vertical profiles of temperature, conductivity, redox potential and dissolved oxygen were measured with submersible multichannel probes YSI 6600. The sulfide concentration was measured in laboratory by an iodometric method.

\section{Results and discussion}

It was shown that stratification stability of the lake increased when the water level increased due to fresh water inflow in 2003-2007. And vice versa, when the lake level was stable or decreasing in 2008-2016 the stability of water column weakened (Rogozin et al., 2017). Thus, we identified a relationship between the stratification regime of the lake and the change in its level, which provides valuable information for paleolimnological reconstruction of the climate humidity in this region of the Southern Siberia using the bottom sediments of Lake Shira.

On the basis of annual observations of purple sulfur bacteria together with physical and chemical profiles we have shown that abundance of purple sulfur bacteria reflected the stability stratification in Lake Shira (Rogozin et al., 2017). In turn, the fluxes of okenone and bacteriochlorophyll a (photopigments of purple sulfur bacteria) in sediment traps and uppermost annual layer of bottom sediments corresponded to the annual changes of purple sulfur bacteria. The profiles of okenone in sediment cores corresponded to the documented changes of water level for the last 100 years. The peaks of okenone corresponded to the level increases whereas the minima of okenone corresponded to the periods of stable or decreasing water level (Fig.1).

\section{Conclusions}

Therefore, we have shown that okenone can be used as a proxy of water level changes in the Lake Shira.

The research was partly supported by Russian Foundation for Basic Research (Grant No. 19-05-00428)

\section{References}

Rogozin D.Y., Tarnovsky M.O., Belolipetskii V.M., et al. 2017. Disturbance of meromixis in saline Lake Shira (Siberia, Russia): possible reasons and ecosystem response. Limnologica 66: 12-23. 


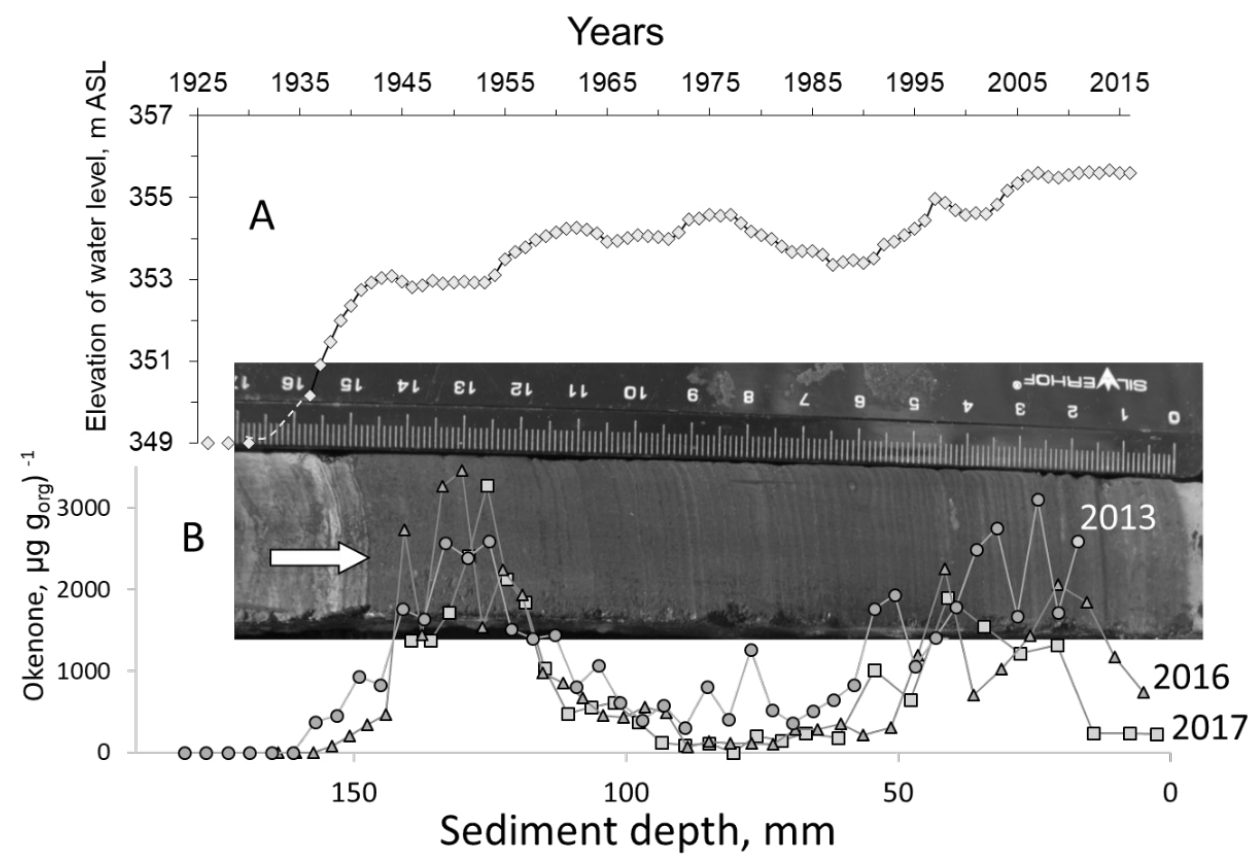

Fig.1. Water level dynamics (A) and concentration of okenone in bottom sediments of Lake Shira (B) 